\title{
The Effect of Hẹamzah Fanșūrì's Mystical Thought To The Muslim Intellectual Tradition in The Archipelago
}

\author{
Fuad Mahbub Siraj \\ Paramadina University Jakarta \\ Address: Jl. Gatot Subroto Kav. 97 Mampang, Jakarta 12790 \\ E-mail: fuad.siraj@paramadina.ac.id
}

Abstract: This discussion aims to explain further the effect of Hamzah Fansuūīi mystical thought to the muslim intellectual tradition in the archipelago. This research is a library research using a historical approach to obtain data and conducting content analysis. This research show that Hamzah Fanșūì was the first in the Archipelago who wrote on mystical thought in a systematic form that had roots in a strong scientific approach and pure of deviation and perfect in reference to Arab sources. From the works of Hamzah Fanșūiri, we can see his mystical style of writing which had a distinctive character, in contrast to other șûfis who lived in the past. Although the influence of waḥdah al-wujūd was still strong, Hamzah Fanșūì was able to transform the term in Arabic into Malay, so it could be understood by people who were unable to speak Arabic. Hamzah Fanșūi provided new technical concepts in Malay; he has made the language fully adequate to discuss the doctrines of philosophical and metaphysical thought formulated by previous șüfís. Ḥamzah Fanșūìi is not only as the originator and pioneer of Sufism wujudiyah in the archipelago, but also as laying the foundations of Islamic studies and integration of Islam and culture.

Keywords: Ḥamzah Fanșūrī, Islamic, mystical, thought, archipelago.

\section{A. Introduction}

The role of the sûfî in the history of Islam in Malay had a higher position in the period between the $12-18^{\text {th }}$ century. During those cent uries, the mariqah 
and the intellectual activities of the Sufis developed well. It can be said that the Islamic works such as history, poetry, mysticism, philosophy, and explanations about mysticism or sulük were primarily the works of Sufis or at least they were related to mysticism and the Sufi's maríqah.

In the Malay world, the birth and the development of Malay literature and the books of religion are the direct impact of the existence of Sufis and their roles played in intellectual activities, education, and creativity (art). It can be seen from their works, that until now there are reference books for people who want to learn the characteristics and the development of mysticism in Malay. Among those Sufis who wrote the influential works of mysticism is Hamzah Fanșūrí. The detailed explanation of wujūdiyyah in Malay language for the first time is found in the works of Hamzah Fanșūīi such as Sharāb al- 'Āshiqīin, Asrār al-'Arifīn and Muntahī (Hadi W. M., 2001: 146-162). The explanation of the tajalli principles of God's Substance is on chapter five of Sharāb al'Ashiqin. It has been said by many experts who studied Hamzah Fanșūri that he was the first in the Archipelago who wrote on mystical thought in a systematic form that had roots in a strong scientific approach. Hamzah Fanșūīi also the first sufi who adopted and deployed the thought of wahdah al-wujüd of Ibn 'Arabi which dominated the religious thought and appreciation among the public. In the middle of the 17th century AD in Aceh, because of Hamzah Fanșūiri, wujūdiyyah doctrine became the subject of debate among the sûfis. The influence of Hamzah Fanșūri's Sufism was broad enough and not only in Aceh but also in other areas in the Archipelago.

Some scholars have conducted the study of Hamzah Fanșürì. The research that has been published about Hamzah Fanșūri and his teaching is the research wrote by Syed Muhammad Naquib al-Attas entitled The Mysticism of Hamzah Fanșüri. Suitable with that title, al-Attas explained the biography and the thought of Hamzah Fanșūīi in the mysticism perspective. Al-Attas also attached three prose of Hamzah Fanșūri and translated to English, those prose are Asrār al- 'A Arifīn, Syarb al- 'Āsyiqīn, Al-Muntahì (in Malay), The Secrets of the Gnostics, The Drink of Lovers, The Adept (translated in English). In his work al-Attas gave the general analysis to the Hamzah Fanșūri mysticism teaching from his works.

The other book is The Poems of Hamzah Fansu üri wrote by G. W. J. Drewes and L. F. Brakel, consist of 32 Hamzah Fanșūì's poetry. Drewes and Brakel explained the live and the journey of Hamzah Fanșüri to the other 
Fuad Mahbub Siraj: The Effect of Hamzah Fanșūî̉'s Mystical Thought To The Muslim Intellectual Tradition in The Archipelago (page 185-210)

places. They also wrote the transliteration and the comments of Syarb al'Āsyiqīin and Al-Muntahì in Java.

In Indonesia, the research on Hamzah Fanșūrì thought wrote by Abdul Hadi W. M. He wrote two titles of books on Hamzah Fanșūiri. The first book is Hamzah Fanșüri Risalah Tasawuf dan Puisi-Puisinya and the second book is Tasawuf yang Tertindas: Kajian Hermeneutik terhadap Karya-Karya Hamzah Fanșūīi. Abdul Hadi in his first book explained that Hamzah Fanșūīi is not only famous as scholars, cultural observer, and man of letters, but also as the reformer in the mysticism area. Abdul Hadi also put the the first literature of Hamzah Fanșūīi in mysticism Zināt al-Wāhidin known also as Zināt al-Muwahhidin and Syair Jawi Fasal fi Bayan 'Ilmu al-Suluk wa alTauhìd in one chapter of his book.

The second book of Abdul Hadi actually is his Ph.D thesis which then published as a book. In that book Abdul Hadi explained how is the idea of love in the Sufism work, esthetic and hermeneutic of sufi. With the hermeneutic approach, Abdul Hadi tries to analysis the hiding spiritual message in the Hamzah Fansuurīi poetries. He also showed that if the history cannot prove the greatest of Hamzah Fanșūīi again, then the works of Ḥamzah Fanșūīi will be the witness or the judge for the question, do he is an infidel sufi or not, like what has been told by the fuqah at that time.

Indonesian scholars who also do a research about the study on Malay world Sufism is Alwi Shihab. He wrote a book on the tittle Akar Tasawuf di Indonesia; Antara Tasawuf Sunni dan Tasawuf Falsafi (The root of Mysticism in Indonesia; Between Sunni Mysticism and Philosophical Mysticism). In this book, Alwi Shihab explained the historical background of mysticism in Indonesia and it's role. He also explained that the root of the mysticism in Indonesia and divided mysticism into two form, sunni mysticism and philosophical mysticism. The root of Sunni mysticism in Indonesia is from the teaching of Nūr al-Dīn al-Rānirī and the root of philosophical mysticism teaching in Indonesia based on the teaching of Hamzah Fanșūri and he explained also the conflict between both of them from the beginning until today. This book emphasizes the historical approach in order to see the development of mysticism in Indonesia and its influence but not to focus on the mysticism teaching of the figures.

Another research has been conducted by Mira fauziah (2013: 289-304) about the mystical thought of Hamzah Fanșūīi. Kiki Muhammad Hakiki 
(2018: 25-58) did a review of the polemic of heresy of Hamzah Fanșūīi by Nur al-Dīn al-Rānirìi.

With using a historical approach to obtain data and conducting content analysis, this research aims to explain further the effect of Hamzah Fanșūì mystical thought to the muslim intellectual tradition in the archipelago. This research is a library research.

\section{B. Sub Section}

\section{The Understanding of Being}

Wahdah al-wuju $\bar{u}$ is a phrase that consists of two syllables, namely waḥdah and al-wujüd. Wahdah means the one, single, or unity (Munawir, 1997: 1538) while al-wujūd means existence (Munawir, 1997: 1543). Amatullah Armstrong gives a definition of waḥdah al-wujūd as the unity of existence, the unity of being, or the unity of invention. At the end of the journey only Allah (SWT) is found (Amstrong, 1996: 111). Thus wahdah alwujūd means a form of unity. Wahdah then is used for a variety of meanings. Among the scholars who interpret wahdah it is something of His Substance that cannot be subdivided into smaller parts. The wahdah word is also used by the philosophers and the suffis as the unity between matter and soul, the substance (essence) and form (shape), among which looks (at birth) and an inner, between universe and God Almighty, because the universe is qādim and comes from God (Nata, 1997: 247).

The term wujūd is usually translated into English as 'being' and 'existence' (Noer, 1995: 41). In addition to the two translations, some added different translations, namely "finding". The word wujüd has been entered into the vocabulary of Indonesian, but it has two ways of being written, namely, "wujud" (with w) and "ujud" (without w), which means "that there is a way and form", 'goal'; 'intent' (Salim, 1991: 1722), "something that has form (can be seen, touched, etc, "real objects, concrete)" (Tim Penyusun Kamus Pusat Bahasa, 2001: 1275). In Arabic, the word wujūd is an isim maf ' $\bar{u} l$ from wajada or wujida, which comes from the root letters $w-j-d$. The mașdar form from same root in Qur'ān is wujūd(Q.S. 65:6). The word of wujūd not only has an objective but also subjective understanding. In the objective sense, the word of wujūd means "found" as a mașdar meaning from wujida and in this sense the word of wujūd is usually translated into English by "being" or "existence". In the subjective sense, the word of wuju $\bar{u}$ as an isim maf ' $\bar{u} l$ from wajada, 
Fuad Mahbub Siraj: The Effect of Hamzah Fanșūî̉'s Mystical Thought To The Muslim Intellectual Tradition in The Archipelago (page 185-210)

means "finding". In the subjective sense the word wujūd is understood through epistemology and objectively through ontology. Both aspects in Ibn 'Arabi's systems of thinking blend harmoniously in what he called wahdah al-wujüd (Noer, 1995: 42).

There are two fundamentally different senses in understanding the term wujūd, first as a concept or that something has existence (Affifi, 1995: 13). The word wujūd was used by Ibn 'Arabi to describe the wujūd of God. The only wujū is wujūd of God; there is no wujūd other than the wujūd of God. It can be concluded that the word wujüd cannot be given to all things other than God. He used his understanding of metamorphosis (Majaz) for anything other than God. The wujū in universe essentially is a wujūd of God which is lent. The relation between God and universe is often described by the relationship between light with darkness, because the wujüd only belongs to God, so 'adam (absence) is a universe attribute. Therefore, Ibn 'Arabi said that the wujūd is light and 'adam is darkness (Noer, 1995: 42).

Ibn 'Arabi distinguishes three categories of wujūd ontologically. The first is the wujūd that must exist. In the language of al-Farābi and Ibn Sinā it is known as Wajib al-Wujūd, that is the wujūd that must exist and there is no one to create it; it manifests all things, and it is an absolute wuju $d$ and this for Ibn "Arabi is God Almighty. The second is the wujūd that exists with God, which for al-Farābī and Ibn Sinā is called mumkin al-wujūd, the wujūd that must exist because the existence of Wajib al-Wujūd, bound or limited (wujūd al-muqayyad). It has wujūd only because of God. From Ibn Arabi's point of view, this is the material of nature and everything in it. The last category is non-wuju or nonexistence ('adam), not hudüs (new) nor qidam (first). Ontologically is God and universe, but at the same time He is neither God nor universe. Thus, it has middle position between the first category and second category (Noer, 1995: 45-46).

Similar to Ibn Arabi's views about the wujūd, Hamzah Fanșūri in Sharb al-'Ashiqin describes that wujūd is only one. From this one existence there is a mask and some forms of content (inner reality). All objects are actually a manifestation of God. Hamzah describes or likens God's wujūd to a sea that does not move, while the universe is an ocean wave of the wuju $\bar{d}$ of God. Hamzah Fansuri said:

Hai Talib!, 'alam ini seperti ombak, keadaan Allah Ta ‘àlā seperti laut; sungguh 
pun ombak lain daripada laut, kepada haqiqatnya tiada lain daripada laut (AlAttas, 1970: 319).

O Seeker! this world is like a wave, God's Existential Mode is the Ocean, though waves and Ocean distinct, yet in reality the waves are not distinct from the Ocean.

Also Hamzah equates the wujūd of God with the Love of God, namely Rahman (Compassionnate) and Rahīm (Merciful) (Hadi W. M., 1995: 22-23). Hamzah said, "Kerana Rahman seperti laut, Ādam seperti buih (for the Merciful is like the ocean and Ādam a bubble)" (Al-Attas, 1970: 319). Rahman and Rahim are from the same word of rahma (Grace). Rahmman is the essential Grace of God and Rahim is the compulsory Grace of God. It is said that Rahma is essential because of the Attributes of God or the manifestation of His Rahim applies to all his creatures, including humans who are Muslims, Christians and Jews. Any creature in the universe is not free from His Rahma. All obtain existence because of His Rahma, and are overwhelmed by His Knowledge that is manifested by a great Love of God. On the other hand, Rahim is His compulsory Mercy, because Rahīm must be delegated to certain people who loved Him with great earnestness, which is the Muslim who are cautious, earnest in worship to Him, and do mushāhadah and Mujāhadah (Al-Attas, 1970: 2324). It can be concluded that Hamzah describes a form of God as Love of God which consists of Rahmman and Rahim. Raḥman is general for all His creatures and Rahim is more specifically delegated to the Muslims who are always obedient in worshiping to Him (taqwā).

\section{The Teaching About God}

According to Ibn 'Arabī, a substance of God cannot be known by reason, and intellect is not able to reach knowledge of Him. He is not the same as those other than Him. Ibn 'Arabī asserts that humans simply must know that He exists, Esa or One in His Ulühiyyah, without His Knowledge about His Substance (Isa, 2001: 60). To provide more information about the Substance of God that cannot be known, Ibn 'Arabī said in Risalah al-Aḥadiyyah as follow:

.... .. there is not something which controls Him except Himself. No one knows Him except Himself.... He knows Himself by Himself. Besides Him there is none that can control Him. His Hijāb which cannot be penetrated is the Oneness of Himself. Apart from Him, nothing surrounds Him. His Hijāb is the reality of His Existence (Burckhardt, 1984: 35). 
Because the Attributes of the Substance of God cannot be known by anyone, then in the thinking of wahdah al-wujūd, Ibn 'Arabi stated that the purpose of the tajalli (appearance) of God is that God Himself can be identified by His Asmā' (Names) and His Attributes. This is the meaning of the secrets of the creation of universe by God in mystical philosophy. For Ibn 'Arabī, the Attributes, Asmā' and $A f^{\prime}$ 'āl of God are the essence in one aspect, or another aspect that is not limited. It is a form of limitation and determinism from the Essence of God. The Attributes and $A f^{\prime}$ 'àl are none other than Names of God which are manifested in the external world. Ibn 'Arabi called it "theater manifestation" (Majlā and Mazhar), a Substance of God to manifest Himself at a different level. Ibn 'Arabī also believes that Attributes, Asmā' and $A f^{\prime}$ 'āl have no existence (a'yān) and the entity of wujūd in the Essence of God. He further said it should be understood that it is only a metaphor (Affifi, 1995: 42).

God, according to the mysticism of Hamzah Fanșūiri is the Essence that is higher, and qādim. The concept of God, namely that there is only God Almighty seems to have a big impact on the thinking of Hamzah in explaining the relationship between the Substance, Attributes, Asmā' and $A f^{\prime} \bar{a} l$ of God. According to Hamzah, the Substance covers the Attributes of God, Asmā' and His $A f^{*} \bar{a} l$, because each relationship is strong. Although the substance, nat ure, Asmā' and $A f^{\prime} \bar{a} l$ were distinguishable from each other according to his understanding, it is a unity that cannot be separated, each of them are interconnected. The existence of this Substance also indicates the Attributes, Asmā' and His $A f^{*} \bar{a} l$. As Hamzah stated:

Adapun sifat Haqq Subḥānahū wa Ta ‘àlā Kamāl. Di bawah ini Jall dan Jaml, karena kenyataan semesta sekalian alam ini di bawah Jalāl dan Jamāl juga. Adapun Dhat lengkap; kepada Jalāl pun serta, kepada Jamāl pun serta, kerana Jalāl dan Jamāl sifat-Nya juga (Al-Attas, 1970: 321).

The Essence is All-Pervasive; It pervades Majesty (the evil) as well as Beauty (the good), for Majesty and Beauty are its Attributes.

In the Qur'an no explanation was found about the relationship between the Substance, Attributes, Asmā' and $A f^{\prime} \bar{a}$ l of God (Isa, 2001: 64). The statement that God Almighty does not declare those things as Attributes of Himself, but the Qur'an refers to them as the names of the Most Beautiful (alAsmā' al-Husnā). 
The explanation of the Substance, Attributes, Asmā' and Af āal of Allah (SWT) by Hamzah Fanșūì view is that the Substance of God is absolute, and has no Name, no Attributes, and no association with anything. The only name given to an absolute substance is Huwa(He). The Substance of God is absolute unity, knowing kunhi (form / essence) God's Substance. The Substance is a Substance of the supreme God, with all other substances beneath it. The Substance of God is called Lā Ta'ayyūn, meaning that it is 'not real'. It is called as Là ta'ayyūn because reasonable thoughts, words, knowledge and human ma'rifah cannot grasp Him. As Hamzah stated:

Ketahui olehmu bahwa kunhi Dhat Allah itu dinamai Ahl al-Sulūk lā ta'ayyūn. Maka lā ta'ayyūn namanya karena budi dan bichara, 'ilmu dan ma'rifah kita tiada tulus kepada-Nya. Jangankan ilmu dan ma'rifah kita, Anbiyā' dan Awliyā' pun hayran (Al-Attas, 1970: 315).

Know that the innermost Essence of God Most Exalted is called by the People of the Path 'indeterminacy'. It is called Indeterminacy because our intelligence and skill in verbal exposition, knowledge and understanding are unable to reach it. Let alone our knowledge and understanding, even The Prophets and the Saints are struck with awe of it.

From the statement of Hamzah it can be understood that the substance was called là ta'ayyūn or kunhi of Allah. From that substance all Attributes and Asmā' of Allah (SWT) appear, but the Attributes and Asma' are annihilated (fana') in the Substance of God Almighty. According to him, there is no other substance higher than the Substance of God. The view about the Substance of God is based also on the hadis of the Prophet (SAW), "Think of what God created, but do not think about His Substance" (Hadi W. M., 1995: 149). It warns us not to think about His Substance. It is impossible for humans to know and understand Him. When the Sufis talk about the principles of creation, God is not talking about substance. That can be achieved by reason and ma' rifah such as the way of creation in stages, starting from the spiritually closest to Him until the spiritually most distant from Him. The description of Hamzah illustrates that God is an absolute Substance that cannot be known through reason, sense or speculation. This opinion seems to be in line with Ibn 'Arabi' 's understanding about God. Even the Substance of God is $1 \bar{a}$ ta'ayyūn, but He wants to be known. Therefore, He created the Attributes, Asma' and His $A f^{\prime} \bar{a} l$ with the intention that He Himself be known. This is seen in the following Hadith Qudsi: 
Fuad Mahbub Siraj: The Effect of Hamzah Fanșūî̉'s Mystical Thought To The Muslim Intellectual Tradition in The Archipelago (page 185-210)

In the beginning I was a hidden treasure, then I wanted to be known, then I created the creatures and they know Me through My self.

The Will to be known is the beginning of the Divine of tajalli (Noer, 1995: 57). After it is done, He is called lā Ta'ayyūn (indetermination), which means 'real'. Ta'ayyün situation can be achieved by the mind, knowledge and ma' $r i$ fah through Attributes, Asmā' and His $A f^{\prime} \bar{a} l$ (Noer, 1995: 42).

Hamzah said that Allah can be known by His creatures, for God Almighty had tajalli of Himself with the Nür Muhammad, who is the origin of the event. The process of self tajalli of God produces the phenomenon of Mazhar (manifestation) of God's Substance. In truth then there is only the manifestation of God Himself; the 'other' is essentially intangible. Hamzah further stated:

Yacni ada-Nya; itu senantiasa ada, yang lain daripada itu senantiasa tiada ada, kerana kepada Ahl Sulūk yang ada juga menjadi ada; yang tiada itu tiada (dapat) menjadi ada. Yacni Allah Subḥnu wa Ta'āla Wājib al-Wujūd, qā'im sendiri-Nya, tiada dengan lain. Mumkin al-Wujūd qā'im dengan Dia. Apabila mumkin al-wujūd qā'im dengan Dia, Hukumnya tiada (ber) wujūd. Kata 'Ulam' 'alam ini daripada tiada diadakan-Nya; sudah diadakan-Nya maka ditiadakan-Nya. Kata ahl Sulūk jika demikian fāsiq-lah Allah Ta'āla atau berhingga. Adapun kepada kami yang tiada itu tiada dapat menjadi ada, yang ada itu tiada kan tiada. Ada kepada șuwari juga lenyap, kepada ma 'nawi tiada lenyap. Seperti umpama yang mati; zahirnya lenyap, kepada batinnya tiada lenyap (Al-Attas, 1970: 317).

That is to say, His Being (Existence), that forever 'is', that which is other than becomes existing; that which 'is' not cannot become existing. By this is meant that God the Glorious and Exalted is Necessary Being, Self-Subsistent, and does not depend for His Existence upon any other. Possible Being is dependent (for its existence) upon It (i.e. Necessary Being). Since Possible Being is dependent (for its existence) upon It, it does not exist in reality. The Doctors of Theology say that the world is brought forth into existence by Him from non-existence; after He has brought forth into existence, He then causes its non-existence; the People of the Path say that if this were so then God the exalted is capricious, or limited (in power). To us, that which is non-existent can never become existent; (conversely) that which exists will never cease to exist. It is only that existence which is formal (i.e. material) that is annihilated; the ideal (i.e. non-material) is not annihilated. Just as one who is dead; his outward manifestation perishes, but his inward hiddenness does not perish. 
Based on the description given by Hamzah, it can be understood that no other entity can exist other than Allah (SWT); the existence which does not exist and which according to Hamzah is called as mumkin al-wujüd while the existence which is only a manifestation of God Almighty is termed as Wajib al-Wujūd. Every substance, including humans vanish under Allah. There is nothing that can maujūd (exist) other than God, while the existence besides God does not exist because the form is supported by Him. Essentially an existence other than Allah is khayalan when compared with the manifestation of Him. Hamzah is a satirical scholar who says that there is a mini-style out of nothing, all that is deemed not exist or vice versa. Hamzah called scholars who do that as fasiq.

The relationship between the Substance and Attributes of God Almighty had raised a theological disputes between the Ash'ariah and Mu'tazilah. The problem revolves around the choice of whether God Almighty has an Attributes (șifat) or not. If God had an eternal Attributes, then the consequense the Attributes is eternal. It is not one, but many. The $\mathrm{Mu}^{\text {'t }}$ azilite resolved this problem by saying that God Almighty does not have an Attributes. For them, God knows Power, Life and others in His Substance (Nasution, 1983: 135). Meanwhile, the Ash'ariah resolved this issue by saying that God has an Attributes. For them the Attributes of Allah is neither His Substance nor a sub substance of His (al-șifat laisa al-dhat wa là hiya gayruhā). According to them, Attributes is not a substance and it is something that is obvious. This is based on the undesrstanding that nat ure is not the same as substance. What is meant by al-ghayriyyah here is to "be separated" (mufarraqah), something other than something specific (Isa, 2001: 65).

In relation with the problems above, Hamzah said that nat ure is not an addition to the substance neither something inherent in the substance. These words, according to him derived from the masters of Sufism. One of them came from Imam al-GhazāTi. Ḥamzah:

Ketahui bahwa șifat Allah yang qadim serta-Nya tujuh: kesatu hayah, kedua 'ilm, ketiga irādah, keempat qudrah, kelima kalām, keenam sami', ketujuh bașar. (Allah itu) qadim dengan sifat yang ketujuh. Adapun jika sifat yang ketujuh ini tiada serta-Nya, naqīs hukumnya, kerana kepada ahl sulūk șifat 'ayn dhät, seperti hayah; dhāt juga yang bernama hayy, seperti 'ilm, dhāt juga karenacilm, maka bernama 'ālim, seperti irādah; dhāt juga karena irādah, maka bernama murīd. Dengan sekalian sifat pun demikian- ilā mā lā nihāyah lahu. 
Fuad Mahbub Siraj: The Effect of Hamzah Fanșūî̉'s Mystical Thought To The Muslim Intellectual Tradition in The Archipelago (page 185-210)

Adapun kata 'Ulamā' șifat 'ayn dhāt pun tiada, ghayr dhät pun tiada; seperti kata Imam Ghazāti:

Sifat allah laysat 'ayn al-dhāt $\bar{i}$

Wa là ghayra siwāhu dha’'I-infișāiti.

Yakni,

Sifat Allah tiada 'ayn dhāt dan

Tiada yang lain daripada-Nya

Bercherai (Al-Attas, 1970: 321).

Know that the Attributes of God that are eternally together with Him are seven: the first is Life, the second Knowledge, the third Will, the fourth Power, the fifth Speech, the sixth Hearing, the seventh Sight. God is eternally together with all these seven Attributes. If these seven Attributes are not (eternally) together, then He is deficient, for to the People of the Path the Attributes are the Very Essence. For example, Life: it is the Essence that, by virtue of Knowledge, is called Knowing; Will: it is the Essence that, by virtue of Will, is called Willing. Similarly with all the Attributes ad infinitum. The Doctors of Theology say that the Attributes are neither the Very Essence nor other than the Essence, as the Imam al-Ghazali (God be well pleased with him!) says:

Sifat allah laysat 'ayn al-dhàtì

Wa lā ghayra siwāhu dha'I-infị̣āli.

That is:

The Attributes of God are neither the Very Essence nor other than He endowed with separation.

From the above quotation it can be understood that Hamzah opinion was taken from the opinions of "masters of Sulük" which stated that Attributes is self mawșūf (Attributes is a substance that is nurtured); there was no difference in meaning, nor is it an addition to the substance and not too attached to substance. Therefore, the sûfís believe as noted by Hamzah, that God Almighty and life with His substance, then He Wishes with His Substance, Knows with His Substance, Hears with His Substance, Sees with His Substance and the Almighty Speaks with His Substance, etc.

Besides the relation with God's Substance, God's Attributes are also often associated with the attributes of creatures. However, the attributes of these creatures do not exist. The reason is given when humans refer to 
themselves. Initially humans do not have any attributes which are inherent, like the Attributes of qudrah, irādah, 'ilm, hayah, and kalām. When born into this world, humans do not have knowledge and also power. Gradually, these attributes develop in man, with God as the basis, the attributes which originally does not exist, then arises as to indicate a source of attributes, the Attributes of Allah. Therefore, one day, the attributes of the gradual emergence inherent in human beings will be gone. Thus, it is holding the attributes of the creatures, merely as loans and not the substance. All existing attributes of creatures are a reality of the Attributes of God (Zulkifli and Santoso, 2008: 314-315).

Furthermore, Hamzah also explains the relationship between Asmā' interrelated with the $A f^{\prime}$ 'āl of God. The Asma' ' of God is the Oneness of God Almighty in every name, that is the Oneness that has a name, because all Asmá, return to wujūd, i.e. God, while the understanding of $A f^{\prime} \bar{a} l$ is the Oneness of Allah Almighty in all actions. Whatever happens in this universe essentially is the $A f^{\prime} \bar{a} l$ of Allah. Everything that happens in this universe, according to Hamzah, can be divided into two main things: first, whether in form (visual) and the content (essence), it means that it is good in appearance, also good in content. Second, it is ugly in the form (visual), but good in the content (essence). It means that when it is seen in the terms of Shari 'ah it is bad, but when it is seen in the terms of essence it is good. For example, a sinner and infidel, in terms of the provisions of personality are considered bad deeds. However, this act is considered good because basically it is a Provision and Act of God the Most Good. As Hamzah described as follows:

Su'al Ahl al-Sulūk kepada 'Ulamā: Islam pun dijadikan Allah, kafir pun dijadikan Allah; kerana apa maka tiada disamakan Allah Subhānahū wa Ta àlā? Islam diberi-Nya ìmān dan ma'rifah, kāfìr diberinya kufr dan shirk; setelah diberi-Nya akan mereka itu iman dan kufr, maka diberi-Nya surga akan Islam, neraka akan kafir-keduanya ilā abadi al-ābād. Kerana nama-Nya 'ādil (mengapa maka perbuatannya itu?) Maka kata ${ }^{c}$ Ulamā': Kerana Ia berbuat sekehendak-Nya. Kata Ahl al-Sulūk: 'Jika (Ia) berbuat sekehendak-Nya, zālim hukumnya, kerana kāfir dapat diislamkan-Nya, mengapa maka dikafirkanNya, sudah dijadikan-Nya kafir maka dimasukkan-Nya ke dalam neraka ilā abadi al-ābād tiada lagi ampun-betapa maka dikatakan 'ādil? (Al-Attas, 1970: 322).

The People of The Path question the Doctors of Theology: 'God creates the believer and $\mathrm{He}$ also creates the unbeliever; why does He not create them all 
Fuad Mahbub Siraj: The Effect of Hamzah Fanșūî̉'s Mystical Thought To The Muslim Intellectual Tradition in The Archipelago (page 185-210)

to be same? To the believer He bestows faith and knowledge of Himself, to the unbeliever He gives infidelity and polytheism; after having given them faith and infidelity He then grants Heaven to the believer and Hell to the unbeliever - to both everlasting (reward and punishment). The Doctors of Theology say: '(He does so) because He does whatever He desires.' The People of the Path say: 'if He does whatever He desires, then He is unjust, for He could have willed that the unbelievers become believers, and yet He causes them to be unbelievers and having caused them to be unbelievers He then cats them into everlasting Hell without any mercy - how then can He be called Just?'.

Hamzah said that human action is essentially from God, and that human beings are not independent. The freedom is the mirror of God's Freedom, which is absolute. Thus, humans can follow his own will which is adjusted to the True Will of God, or he may also follow his own will and desires in this world. Those things are in line with the phrase which states that "The world is also derived from God, but his wujūd is not the real wujūd. If people follow this world, they are deceived. Whereas if they make this word singular, it means that they find their true attributes and their true destiny (Al-Attas, 1970: 233-240).

We should know that God Almighty does a good thing with His Love and God is also the Designer who determined everything in this world. His Oneness Actions are associated with His Shari 'ah (Divine law) or the laws of destiny and the natural law (sunnah allāh) which are determined by Him. Hamzah Fanșürì also encourages us to believe in the Attributes, Asmā' and Af'āl. He stated:

Adapun Dhàt itu, sungguh pun dibawa kepada ibarat, kepada kunhinya tiada siapa tahu, kerana Ia tiada dapat di ibaratkan. Sungguh pun Esa, tiada dengan esanya; sungguh pun Tunggal, tiada dengan tunggalnya. Barang Sifat, Dht, Asmā' kita nisbatkan kepadaNya ibarat juga.

The Essence - although it can be described by means of verbal expression in reality is unknowable, its absoluteness is not related to anything; although It is One and Only, its oneness and singleness are not related to anything. We attribute to its Essence, Attributes and Names as expressions only (Hadi W. M., 1995: 97).

From the explanation and the description above it can be concluded that when we take the opinion of Hamzah about the Attributes, with $A f^{\prime} \bar{a} l$ of God in general, we find a similarity with the opinion of Ibn 'Arabì. For Ibn 'Arabī 
all these things cannot be separated, although the Attributes, Asmā' with $A f^{*} \bar{a} l$ can be separated according to their understanding. However, all things accumulate in a God, who is absolute and qadim.

\section{The Creation of The Universe}

The doctrine of the creation of the universe of Hamzah Fanșurīi can be related with Ibn 'Arabi's doctrine of creation. Both of these teachings equally believe that the universe was created from something that exists to exist, not created from nothing into being (creatio ex nihilo). The universe is qadim, the universe exists, created through a process of tajalli, namely the manifestation of the eternal self and without end. Tajalli is a process of self-appearance of God in forms that have been determined and devoted, that called Ta'ayyun (determination).

The theory about the creation according to Ibn 'Arabi rests on the understanding that the wujūd is essentially one, i.e. Wujūd of Allah, which is absolute. The Wujūd of God that is absolute which has tajalli through the following three stages (Isa, 2001: 73-75):

a. The stage of ahadiyyah (unity), which is also called the stage of dhätiyyah. In this stage the Wujüd of Allah which is absolute still cannot be understod and imagined.

b. The stage of wăhidiyyah, the Substances of God has tajalli in the Attributes and Asmā' of God. This is called al-a yān al-thäbitah (fixed essence) which is also named as ta ayyun awwal (first determination). In this stage the wujū which is real is still the Wujūd of Allah.

c. The stage of tajalli shuhüdi which is called as ta ayyun thäni (second determination). In this stage God has tajalli still through Asmā' and His Atributes in the empirical reality. Thus, al-a 'yān al-thābitah (fixed essence) or ta'ayyun awwal (first determination), which is in the second stage is still a potentiality of Wujūd in God Substance which now becomes a wujūd or an actual reality in the empirical realm. This nature is a collection of God's tajalli empirical phenomena in the variety of wuju $d$ or forms which have no limit.

The process of God's tajalli takes place beyond space and time, there is neither beginning nor end, and He derives from that single essential to manifest Himself in external realities. The goal is that God can be known through His Asmā' and His Attributes which have tajalli to this world. The theory of creation of Ibn 'Arabi was then known by the term that the nature 
Fuad Mahbub Siraj: The Effect of Hamzah Fanșūî̉'s Mystical Thought To The Muslim Intellectual Tradition in The Archipelago (page 185-210)

is "the Breath of the Merciful" because creation is based on the "Love", the Essential Image of God. Ibn 'Arabi's theory also influenced 'Abd Karim alJili. He mentions that the processes of tanazzul (down hierarchy), or God's tajalli consists of three stages, namely ahadiyyah, huwiyah and iniyyah. On the stage of ahadiyyah, God in His Absolute just comes out al-a'ma, while huwiyah is still not invisible reality, but under ahadiyyah, the Attributes and the Asmā' are in the form of potentials. The last stage, iniyyah, is the Appearance of God with the Names and His Attributes on creatures (Isa, 2001: 7576).

The principal idea of the best known of Hamzah Fanșūri is the five stages of wujūd. The five stages is a depiction about the process of the universe that remain valid when the universe appears as a manifestation of Allah's Substance which is initially spiritual and then proceeds to be physical. The teaching of wahdah al-wujūd often attributed to Ibn 'Arabī, although he himself never argued this term. A student as well as stepchildren of Ibn 'Arabi named Qunawi who used this term firstly describes that the Oneness of God is not opposed to the idea of appearance (tajalli) of His Knowledge of all kinds (Shadiqin, 2008: 66-67).

Ḥamzah Fanșūīi, in the work of Sharāb al-'Ashiqīn, when he talked about the creation, seemed to be influenced by the theories of Ibn 'Arabī and al-Jili, i.e. the appearance of God Image, from the point of ontology, called by Ibn 'Arabī and al-Jili tajalli. Meanwhile, Hamzah Fanșūri mentions the stages with Ta'ayyun (determination). According to Hamzah, there are four stages of Ta'ayyun. Before entering that level, God is in His Solitude which is termed by Hamzah Fansuri as $L \bar{a}$ Ta'ayyun (indetermination). After that, there is Ta'ayyun Awwal (appearance of Himself in the first stage or called first determination), in which God reveals Himself in the image of 'ilm (knowledge), wujūd (being), shuhūd (Sight) and Nür(light). In Ta'ayyun Thāni, the second stage (second determination) of the apparitions of Himself, God reveals Himself in the prototype image of the universe, called al-A 'yn Thäbitah or fixed essence. In the third stage Ta'ayyun Thälith (third determination), God appears in the image of the human spirit and creatures. Then, in the fourth-and fifth-stages are Ta ayyun Rabi' and Khämis (fourth and fifth determination), God reveals Himself in the image of empirical nature. After that, there has been a never-ending process of tajalli.

Hamzah Fansuūì provides the following imagery associated with Tajalli 
or Ta'ayyun (determination) of God:

Ketahui olehmu bahwa kunhi Dhat Allah itu dinamai Ahl al-Sulūk lā ta'ayyun. Maka lā ta 'ayyun namanya kerana budi dan bichara, 'ilmu dan ma'rifah kita tiada lulus pada-Nya. Jangankan 'ilmu dan ma'rifah kita; Anbiyā' dan Awliyā', pun hairan. Olehnya itu maka sabda Nabi: "Subhanaka mā 'arafnāka haqqa ma 'rifataka." (ya ni: "Amat Suci-Mu!, tiada kukenal sebenar kenal akan Dikau"). Dan lagi Sabda Nabi: "Tafakkarū fì khalq allāh wa lā tafakkarū fì Dhāt allāh" (ya 'ni: "Kamu fikirkan dalam yang dijadikan Allah; bermula: jangan kamu fikirkan Dhat Allah.") Kerana ini maka dinamai Ahl al-Sulūk lāta 'ayyun. Mána lā ta “ayyun" tiada nyata.

Adapun pertama ta'ayyun empat bahagi: 'ilmu, dan wujūd, dan shuhūd, dan nür. Ya'ni ta'ayyun keempatnya inilah yang bernama ta'ayyun awwal, kerana daripada 'ilmu maka 'alim dan ma'lum nyata; kerana wujūd maka yang mengadakan dan yang diadakan nyata; kerana shuhüd maka yang melihat dan yang dilihat nyata; kerana cahaya maka yang menerangkan dan yang diterangkan nyata. Sekalian ini daripada ta'ayyun awwal jua; 'alim dan ma'lum, awwal dan akhir, lahir dan batin beroleh nama (Al-Attas, 1970: 315).

Know that innermost Essence of God Most Exalted is called by the People of the Path 'indeterminacy'. It is called Indeterminacy because our intelligence and skill in verbal exposition knowledge and understanding are unable to reach it. Let alone our knowledge and understanding, even the Prophets and the Saints are struck with awe it. Hence the Prophet said: "Glory to be Thee! We cannot really know Thee". And the Prophet said further: "Contemplate upon His creation and not upon His Essence." This is why the people of the Path call this (Essence) indeterminate, meaning non-manifest.

The first (stage) of determinacy is fourfold: Knowledge, Being, Sight, and Light. All these four are called the First Determination, for by virtue of Knowledge the Knower and the Known become manifest; by virtue of Being that which causes to be and That which becomes are manifest; by virtue of Sight the Seer and the Seen are manifest; by virtue of Light the Illuminator and the Illuminated are manifest. All these - the Knower and the Known, the First and the Last, the Manifest and the Hidden - are of the First determination.

According to Hamzah Fanșūri, Ta'ayyun Awwal (first determination) is likened to the sea. If the sea is choppy and the sea water evaporates into the air to form clouds, then the water vapor is called al- $A$ 'yan Thäbitah (fixed essence), or in other words it is at the stage of Ta'ayyun Thäni. Then the water vapor forms clouds that undergoes a process of condensation which can reduce the rain water which falls in various places on the earth. Precipitation is 
Fuad Mahbub Siraj: The Effect of Hamzah Fanșūî̉'s Mystical Thought To The Muslim Intellectual Tradition in The Archipelago (page 185-210)

described as Ta'ayyun Thâlith (nature of spirit), the nature of spirits under the statement of Kun Fayakūn, so there it becomes the nature of spirits. The rain fall on the earth is called a river. Rain water that forms the river is described as Ta 'ayyun Rabi' and Khämis ('alam mithal) in which there is the creation of the universe, the creatures, including humans. The creation is endless and infinite. In the end, the river empties into the sea and like all of His creations will return to Him. Further explanation about the Ta'ayyun of God is, that the appearance or reality of the first stage of God, which Hamzah Fansuri calls Ta'ayyun Awwal (the stage of wahdah), contains a plurality of unity, which is still in the form of ijmāl (outline). The Reality of God in the first stage consists of: 'ilm (knowledge), wujūd (being), shuhūd (see, watch), and Nür (light). With the knowledge then God is in itself 'ālim (knowing or omniscient), and ma' $\operatorname{lum}$ (known). Since He is Wujüd, then by itself He is the Existence, who creates the existence. Because of the light, He is the Explainer (with the light of His) (Al-Attas, 1970: 150) and described (by His lights). However, all of that still does not separate.

In the first stage comes from the Substance of God any Attributes and His Asmā' universally. This stage is a single unit containing a plurality. This stage, according to Hamzah Fanșūìi, obtains the essence of Muhammadiyyah (Nür Muhammad). That is like the science of God to the Substance, Attributes and His Asmā', and to all reality as a whole. There is no separation of one to another; it is the beginning of reality. The stage in Ta'ayyun Awwal is unity, rather like seeds, in which its parts, such as branches and leaves still are one within the seed. It can also be likened to a node (point) within the sphere which is the origin for all letters, containing all the letters that would be written, but there is intact aggregate inside the reality of letter. The letter is integrated into one the limits of which are not seen (Simuh, 1988: 323). In his Sharāb al- 'Ashiqīn, Hamzah gives the parable of Ta'ayyun Awwal as the sea, namely:

Adapun ta'ayyun awwal dinamai Aḥad pun namanya, Wāhid pun namanya. apabila kita lainkan Dhät semata Sendirinya Aḥad namanya, apabila kita sertakan sifatnya dengan 'ibaratnya, wāhid namanya, kerana Ahad itulah bernama Wāḥid, memegang 'alam sekalian dari pertamanya hingga kesudahannya (Al-Attas, 1970: 316).

The First Determination may be called (both) ahad or wähid. When we regard the Essence by itself it is called ahad, but when we regard the Essence together 
with Its Attributes and names then it is called wāḥid, for aḥad is wāḥid sustaining the universe and holding it together from its beginning to its end.

After that he explains:

'The sea is the sea, as it was before,

The 'new' are waves and rivers;

Let not forms that resemble them veil thee,

For the shapes they form are but veils.'

But (the waves) are together with the eternal sea. As the distich says:

The sea is eternal: when it heaves

It is then called by the name 'waves'...

But its real essence is the sea, for sea and waves are not two (entities), but one and the same (Al-Attas, 1970: 37-38).

In the quotation above, Hamzah gave the analogy of ta'ayyun awwal like sea water, wave, and the river, which then evaporates into vapor and into clouds. Rain then descends from the clouds. This process begins from a drop of sea water that will produce the oceans, rivers, and rains. It is a drop of sea water that is called Ta'ayyun 'Awwal.

After the Ta'ayyun Awwal stage, God has tajalli to the second stage (Ta'ayyun Thānī) which is also called as wăhidiyyah stage. The Ta'ayyun Thāni (the second determination), also known as Ta'ayyun Ma'lüm, depicts reality of God in the second place. In this stage, all which are pent has to be distinguished clearly and in detail. However, it has not appeared in the nature of reality. Each unit has a clear limitation in the science of God. He is known or unknown. God Knowledge or Science reveals Himself in the form of 'known' or 'unknown'. The Knowledge of God, which is called as al- $A$ 'yān Thāabitah (fixed essence), is the reality of all things. Al-A 'yān thābitah is also called șuwar al-'Ilmiyyah, the known form or al-ḥaqiqah aṣl- ashyra; aṣl-ashyā', is the essence of things in the universe and the spirit of idăfĩ, the soul adrift (Hadi W. M., 1995:150).

Adapun Ma'lūm itulah yang dinamai Ahl al-Sulūk a'yān thābitah. Setengah menamai (dia) ḥaqīah al-ashyā', setengah menamai (dia) șuwar al-'ilmiyyah, setengah menamai (dia) rụh ị̣ấfí. Sekalian ini ta 'ayyun thāni hukumnya (AlAttas, 1970: 316).

The known is called by the People of the Path the Fixed Essence. Some call it the Essence of Things, some the Cognitive Forms, and others call it the Relational Spirit. All these are the Second Determination. 
Both of the aforementioned stages, Ta ayyun Awwal and Ta ayyun Thānī are forms of inner universe which are qādim and thäbitah (remain in the science of God - nothing changed since $q \bar{a}$ dim). From the two inner stages emerged two new seen stages, called as $A$ 'yān Khärijiyyah (potential existents). They are Ta'ayyun Thālith (the stage of 'Alam al-Rüḥ) and Ta'ayyun $R a b i$ ' and Khāmis (the stage of 'Alam Mithsāl).

Ta'ayyun Thālith (the stage of 'Alam al-Rūh), which is natural of all spirits, a form of subtle body of jism latîif. As jism lațîf, 'Alam al-Rūḥ is not seen by the five senses and eyes of the heart (feelings), and cannot be likened to the situation. In this stage the reality that flows out takes the form of 'Alam al-Rüh. The essence of this nature is one, only the aspect which is divided into the human spirit, animal spirit and plant spirit. Of this, Hamzah stated that, "Adapun rūḥ insān dan rūh hewani dan rūḥ nabati Ta ayyun Thālith hukumnya" (Now the spirit of human, animals, and vegetal in the stage of Ta'ayyun Thālith).

The latest stages according to Hamzah are Ta 'ayyun Rabi' and Khāmis (the stages of 'Alam Mithāal). The reality of God in the fourth and fifth stage is the creation of the universe, the creatures, including humans. The creation is endless and infinite. The creation of this endlessness is termed ilā mā la nihayah lahu, because if God does not do creation then God cannot be known as the creator (Hadi W. M., 1995: 39).

Adapun ta'ayyun rabi' dan khāmis, ta'ayyun jismānì kepada semesta sekalian makhlūqāt, kepada tiada berkesudahan dan ta'ayyun juga namanya.

The Fourth and Fifth Determinations encompass the realm of physical things in its entirety, comprising the whole universe and all created things (herein).

Thus, together with $L \bar{a} T a$ 'ayyun there are five stages of the Tajalli of God. Therefore, this teaching can be said to be the teaching of the five stages and not the seven stages.

The works of Hamzah, especially those seen in several passages in his book, allows him to be classified as a follower of wahdah al-wujūd, as taught by Ibn 'Arabì. In another work entitled Asrār al-'Arifin, Hamzah likens the relationship of the universe and God to the sun and light, where the light and the sun are an inseparable unity. However, in essence they are different (Hadi W. M., 1995: 39). Hamzah stated the following:

Adapun kepada 'Ulamā' shari 'at Dhāt Allah dengan wujūd Allah dua 
IBDA': Jurnal Kajian Islam dan Budaya

hukumnya; wujūd 'ilmu dengan 'ālim dua hukumnya; wujūd 'ālam dengan 'ālam dua hukumnya; wujūd 'ālam lain wujūd Allah lain. Adapun wujūd Allah dengan Dhät Allah misal matahari dengan cahayanya; sungguhpun esa pada penglihat mata dan penglihat hati, dua hukumnya: matahari lain cahayanya lain.

Adapun 'ālam maka dikatakan wujūdnya lain kerana 'ālam seperti bulan beroleh cahaya dari matahari. Sebab inilah maka dikatakan 'Ulamā': "Wujūd 'ālam lain daripada wujūd Allah. Wujūd Allah dengan Dhät Allah lain”.

Maka kata Ahl al-Sulūk: Jika demikian, Allah Ta'ala di luar 'ālam atau dalam 'ālam dapat dikata; atau hampir kepada 'ālam atau jauh daripada 'ālam dapat dikata”. Pada kami, Dhāt Allah dengan wujūd Allah esa hukumnya; wujūd Allah dengan wujūd 'ālam esa... (Al-Attas, 1970: 242).

According to the 'Ulama' ' of the Prescribed Law, the judgment concerning the Essence of God and His Being is that they are two; (similarly,) the being of knowledge and knower are two; the being of the universe and the universe are two; the being of the universe is different from the Being of God. The Essence of God and His Being is like the sun and its light: although they are one to external and internal perception, the judgment is that they are two: the sun is different from its light.

As to the universe, the reason why it is said that its being is different (from that of God), is because the universe is like the moon deriving its light from the sun. This is the reason why the 'Ulam' say: "The being of the universe is different from the Being of God. God's Being and His Essence are different".

The People of the Path say: "If this is the case, then God can be referred to as being 'outside' or 'in' (the universe); or 'near' the universe or 'far' from it". To us, the Essence of God and His Being is one; His Being and the being of the universe is one...

Seeing the aforementioned parable by Hamzah Fanșūiri, it appears that he is like Ibn 'Arabi, who called a universe to God with two Attributes, which are tanzīh (transcendent) and tashbīh (immanent). In terms of the Substance of His Absolute Attributes Là Ta 'ayyun is tanzīh, while in terms of both tajalli even tajalli of Substances (al-a 'yān al-thābitah) and tajalli of potential existents (al-a'yan al-khārijiyyah) is tashbīh (immanent). In the explanation above, Hamzah, on the side of tanzīh, essentially distinguishes between God and the 
Fuad Mahbub Siraj: The Effect of Hamzah Fanșūî̉'s Mystical Thought To The Muslim Intellectual Tradition in The Archipelago (page 185-210)

universe. Although God and the universe are essentially the same, they have different attributes, where God has His own distinct essence to the universe.

\section{The Effect of Hamzah Fanșūrí's Doctrine to The Muslim Intellectual Tradition In The Archipelago}

The wahdah al-wujūd concept is regarded as one Sufism doctrines which were influenced by philosophy and various other non-dogmatic sources (AlAttas, 1970: 210). The Wahdah al-wujūd doctrine is part of the intellectual genealogy of texts developed from Greece, Persia and India which were translated into Arabic. However, sources which describe that the wahdah al-wujūd as not coming from Islamic teachings usually originated from Western Orientalists. This is because they identify these teachings not from the Islam, but are built based on the logic of thinking influenced by social situations. The efforts to identify Islam with other religions or thoughts are not entirely correct, because the teachings of Islam are based on the revelation of the Qur'ān and hadith. The Qur'ān is a source that is not derived from the product of human thought, but a revelation from Allah (SWT). Simultaneously, the Qur'an and hadith sometimes appear in a format that can be used not just in its application, but must prior be elaborated and developed by the mind. Thus, there is a part of Islamic teachings that are normative doctrine, namely those based on the Qur'ān and hadith which cannot be amended, meanwhile there are also non-normative doctrines, those rooted in the mind that can be developed and even changed (Nata, 1997: 188-189).

The doctrine of wahdat al-wujūd of Ibn 'Arabi also has a relationship with the type of Islamic mysticism that can be found in the mystical studies of Abu Yazīd al-Bistmi and al-Hallāj. The biggest influence comes from Ibn 'Arabī and in his books entitled especially Futūhāt al-Makkiyyah and Fuṣuṣ al-Hikam. The doctrine of wahdah al-wujüd of Ibn 'Arabi was very popular in the late 16th century and early 17th-century AD in various areas, particularly in Aceh. The thought of wahdah al-wujūd of Ibn 'Arabi dominated the religious thought and appreciation among the public, especially because it had been adopted and deployed first by the leaders of the süfi of Aceh most revered, i.e., Hamzah Fanșūiri. In the middle of the 17th century AD in Aceh, after the death of Hamzah Fanșūí, wujūdiyyah doctrine was once again the subject of debate among the süfís. In addition, because of the current social and political factors that affected each party in the dispute, controversy surrounding the 
teaching of wujüdiyyah was also caused by the differences in interpreting the teaching. Such intense controversy resulted in a tragedy in Aceh, namely the burning of the works of the mystical Hamzah Fanșuri and Shams al-Dìn that includes the teaching of wujūdiyah by Nür al-Dīn al-Rānirì (d. 1068 H/1658 $\mathrm{M})$ and his followers as well as persecution and murder of those who refused to abandon the doctrine (Fathurahman, 1999: 21).

The influence of Hamzah Fanșūrì's Sufism was broad enough and not only in Aceh but also in other areas in the Archipelago. In Java, for example, the works of Hamzah Fanșūri were disseminated down to Banten, Cirebon, Pajang, and even to Mataram, Buton, and South East Sulawesi. This was through two of his works, namely Sharāb al- 'Ashiqīin and Asrār al-'Arifīn. The existence of two manuscripts in Buton was an indication that the teaching of Hamzah Fanșūri had been learned by everyone in that area (Mulkan, 2005: 8).

Since the $17^{\text {th }}$ century AD, the mysticism and teaching of wahdah alwuju $\bar{u}$ in Java existed in the form of manunggaling kawulo gusti (the unity of humans and Allah), which was taught by Shaykh Siti Jenar (Mulkan, 2005: 8), and still hold out in the history of Islam in Java (Teeuw A, 1995: 67). At the end of the 17th century AD the manuscript of Sharāb al- 'Āshiqīn was translated into Javanese in conjunction with the spread of understanding of wujüdiyyah in Java. The manuscript was found in Banten, precisely in the personal library of Sultāan Abū al-Mạ̣asin Zayn al- '⿳亠丷⿵冂bidin, the king of Banten from the years 1690-1733 AD. This sultān was a lover of Sufism and a student of a great șüfí from Makasar, named Shaykh Yūsuf al-Maqassari (d. 1114 H/ 1699 M) (Hadi W. M., 1995: 147).

The influence of wahdat al-wujud doctrine of Hamzah Fanșūri is also found in a poem which very similar to Hamzah Fansuri's poetry. This shows that as a traveler figure, Hamzah Fanșūi is expected to have made a pilgrimage to the island of Java, after visiting other places that are considered important (Arifin, 2013: 45).

Through the writings Sharb al-'Āshiqin and other works, the mystical thought of Hamzah Fanșūri was known by the Muslims in the archipelago. Hamzah Fanșūi was an adherent of the school of philosophical mysticism of waḥdah al-wujūd or wujūdiyyah (Hadi W. M., 1995: 147). His worldview was revealed in his prose and poetry. The Malay religious books during Hamzah Fanșūi grew rapidly, along with the spread of Islam throughout the archipelago and the establishment of royal Malay-Muslims in several places, 
Fuad Mahbub Siraj: The Effect of Hamzah Fanșūî̉'s Mystical Thought To The Muslim Intellectual Tradition in The Archipelago (page 185-210)

namely in Pasai, Malacca and Acheh. Those religious books contain jurisprudence, doctrine, mysticism, and so forth. In this case, Hamzah Fansuūīi was one of the renowned authors of religious books which are aligned with those of 'Abd al-Ṣamad al-Falimbānì (d. 1203 H/1788 M), and Shaykh Muḥammad Nafīs (d. $1225 \mathrm{H} / 1812 \mathrm{M}$ ).

It has been said by many experts who studied Hamzah Fanșūri that he was the first in the Archipelago who wrote on mystical thought in a systematic form that had roots in a strong scientific approach. From the works of Ḥamzah Fanșūì available today, we can see his mystical style of writing which had a distinctive character, in contrast to other sufîs who lived in the past. Although the influence of wahdah al-wujūd was still strong, Hamzah Fanșūīi was able to transform the term in Arabic into Malay, so it could be understood by people who were unable to speak Arabic. Hamzah Fanșūrì himself said in the introduction of his book, Sharāb al-'Asshiqīn, which he purposely wrote his verses in Arabic-Malay for people who did not understand Arabic and Persia so that they could study mysticism (Hadi W. M., 1995: 59). What had been done by Hamzah Fanșūri was not only be seen as an attempt to spread the idea of mysticism, but also as a first step to the birth of Malay literature, especially in the field of prose and poetry (Fang, 1993: 236).

Hamzah Fanșūiri brought and developed the ideas of philosophical mysticism to the Archipelago. He was the first person who promoted philosophical mysticism in the archipelago which was clean and pure of deviation and perfect in reference to Arab sources (Shihab, 2001: 123). Furthermore, what had been done by Hamzah Fanșūrī was that he provided new technical concepts in Malay; he has made the language fully adequate to discuss the doctrines of philosophical and metaphysical thought formulated by previous sûfîs (Shadiqin, 2008: 76).

In the development of the history of Islamic thought in the archipelago, Hamzah Fanșūri was not only regarded as a pioneer in the existence of the Sufism genre alone, but in subsequent studies, it was evident that Hamzah Fanșüri had become a pioneer in the study of Islamic and cultural studies in the archipelago. There are so many works of scholars and researchers who discuss Hamzah Fanșūri in various aspects of science, whether it is sufism, religion, literature, culture, language, and so on social and political life. In connection with the study, according to the author's observations, there are 
dozens of studies on Hamzah Fanșūrì with various aspects, including: Studies by Wan Mohammad Shaghir Abdullah who wrote two studies, namely Hamzah Fanșūīi Poetry and Sufi and Al-Makrifah Works: Various Aspects of Tasawuf in The Archipelago. This paper provides information about the person as a mystic Sufi poet Ḥamzah Fanșūri The Malaya. The same was done by Abdul Hadi WM. about Hamzah Fansuri: The Tasawuf leaflet and its poems. It is said that in this study, Hamzah Fanșūīi was a reformer of Sufism. So did Abdul write about Hamzah Fanșūiri: an Aceh sufi poet. The works of Edward Djmaris and Saksono Prijanto wrote Hamzah Fanșūrì and Nuruddin Ar-Raniri.

Vladimir Braginsky wrote Some Remark on The Stucture of The Poetry of the Boat by Hamzah Fanșūir. Similarly, Syarifuddin wrote about the existence of Hamzah Fanșūrì in the Scholars’ Debate. Syed Naquib al-Attas wrote The Mysticism of Hamzah Fanșūìi. Then M. Afif Anshory wrote the Thesis of the Book of Philosophy of Hamzah Fanșūiri. Sultani wrote a Thesis entitled Al-Insan al-Kamil in Hamzah Fanșūì Concept. Also Claude Guillot \& Ludvik Kalus wrote Ḥamzah Fanșūī's tombstone. Then Mardinal Tarigan also wrote a Dissertation on UIN-SU Fields on Sufistic Values in Hamzah Fanșūri's Poems: Thematic Analysis of the Book of Asrār al-Arifin. A. Jhons's study of The Poems of Hamzah Fanșūri in 1990, published in the Dutch Journal of Leiden, has also shown that Hamzah Fanșūīi was the greatest Sufi figure of all time. If there are more studies on this Hamzah Fanșūìi, it is from researchers in the archipelago and from outside (the West). Thus, the study of Hamzah Fansuurīi is actually alive and growing in line with the development of Islamic studies.

Ḥamzah Fanșūrī's existence as a pioneer, reformer of Islamic studies especially in the field of Islamic thought and poetry — has found its true identity. He is not only as the originator and pioneer of Sufism wujudiyah in the archipelago, but also as laying the foundations of Islamic studies who is always in dialogue and dialectic with time and place, namely the meeting between Islam and culture / Malay tradition.

\section{Conclusion}

The principal idea of the best known of Hamzah Fanșūin is the five stages of wujü. The five stages are a depiction about the process of the universe that remain valid when the universe appears as a manifestation of Allah's Subs- 
Fuad Mahbub Siraj: The Effect of Ḥamzah Fanșūrỉ's Mystical Thought To The Muslim Intellectual Tradition in The Archipelago (page 185-210)

tance which is initially spiritual and then proceeds to be physical.

The influence of Hamzah Fanșūrì's Sufism was broad enough and not only in Aceh but also in other areas in the Archipelago. Through the writings Sharb al- 'Āshiqin and other works, the mystical thought of Hamzah Fanșüri was known by the Muslims in the archipelago. Hamzah Fanșūiri brought and developed the ideas of philosophical mysticism to the Archipelago. He was the first person who promoted philosophical mysticism in the archipelago which was clean and pure of deviation and perfect in reference to Arab sources. What had been done by Hamzah Fanșūì was not only be seen as an attempt to spread the idea of mysticism, but also as a first step to the birth of Malay literature, especially in the field of prose and poetry, because his worldview was revealed in his prose and poetry.

\section{REFERENCES}

Al-Attas, Syed Muhammad Naquib. 1970. The Mysticism of Hamzah Fansuri. Kuala Lumpur: ISTAC.

A, Teeuw. 1995. Indonesia antara Keberlisanan dan Keberaksaraan. Jakarta: Pustaka Jaya.

Amstrong, Amatullah. 1996. Kunci Memasuki Dunia Tasawuf. translated by M. S. Nasrullah and Ahmad Baikuni. Bandung: Mizan.

Affifi, E. 1995. Filsafat Mistis Ibn 'Arabī'. translated from A Mystical Philosophy of Muhyidin Ibn 'Arabì', Sjahrir Mawi and Nandi Rahman. Jakarta: Gaya Media Pratama.

Arifin, Miftah. 2013. Sufi Nusantara: Biografi, Karya Intelektual dan Pemikiran Tasawuf. Yogyakarta: Ar-Ruzz Media.

Burckhardt, Titus. 1984. Mengenal Ajaran Kaum Sufi, translated by Azyumardi Azra. Jakarta: Pustaka Jaya.

Drewes, G. W. J, L. F. Brakel. 1986. The Poems of Hamzah Fansuri. Dordrecht-Holland: Foris Publication.

Mira Fauziah. "Pemikiran Tasawuf Hamzah Fansuri", Jurnal Substantia Vol. 15 No. 2 (2013): 289-304.

Fathurahman, Oman. 1999. Tanbih al-Masyi, Menyoal Wahdat al-Wujud, Kasus Abdurrauf Singkel di Aceh Abad 17. Bandung: Mizan. 
Hadi, W. M. Abdul, 1995. Hamzah Fansuri: Risalah Tasawuf dan PuisiPuisinya. Bandung: Mizan.

Hakiki, Kiki Muhammah, "Tasawuf Wujudiyyat: Tinjauan Ulang Polemik Penyesatan Hamzah Fanșūri oleh Shaykh Nur al-Din al-Raniri”, Jurnal Theologia Vol. 29 No. 1 (2018), 25-58.

Isa, H. Ahmadi. 2001. Ajaran Tasawuf Muhammad Nafis dalam Perbandingan. Jakarta: Raja Grafindo Persada.

Mulkan, Abdul Munir. 2005. Ma'rifat Siti Jenar. Jakarta: Grafindo.

Munawir, Ahmad Warson. 1997. Kamus al-Munawir Arab-Indonesia. Surabaya.

Noer, Kautsar Azhari. 1995. Ibn Al-'Arabī: Wahdat al-Wujūd dalam Perdebatan. Jakarta: Paramadina.

Nasution, Harun. 2002. Teologi Islam: Aliran-aliran Sejarah Analisa Perbandingan, Vol. 5. Jakarta: Universitas Indonesia.

Nata, Abuddin. 1997. Akhlak Tasawuf. Jakarta: Raja Grafindo Persada.

Salim, Peter and Yenni Salim. 1991. Kamus Bahasa Indonesia Kontemporer. Jakarta.

Sangidu. 2003. Wachdatul Wujud; Polemik Pemikiran Sufistik antara Hamzah Fansuri dan Syamsuddin as-Sumatrani dengan Nuruddin Ar-Raniry. Yogyakarta: Penerbit Gama Media.

Sentot Budi Santoso, Zulkifli. 2008. Wujūd (Menuju Jalan Kebenaran). Solo: Mutiara Kertas.

Shadiqin, Sehat Ihsan. 2008. Tasawuf Aceh. Aceh: Bandar Publishing. Simuh. 1988. Mistik Islam Kejawen Raden Ngabehi Ranggawarsita Suatu Studi Terhadap Serat Wirid Hidayat Jati. Jakarta: Universitas Indonesia Press.

Tim Penyusun Kamus Pusat Bahasa. 2001. Kamus Besar Bahasa Indonesia. Jakarta.

Yunus, Abdul Rahim. 1995. Posisi Tasawuf dalam Sistem Kekuasaan di Kesultanan Buton pada Abad ke-19. Jakarta: Indonesia-Netherlands Cooperation in Islamic Studies (INIS). 